\title{
Effect of Growth and Yield of Brinjal (Solanum Melongena L.) Grown Under Different Poly Mulches
}

\author{
H.D.S.N. Wijesooriya ${ }^{1}$, R.D.N. Debarawatta ${ }^{1}$, K. Yakandawala $^{1}$, R. Dabarera ${ }^{2}$ \\ and W.A.P. Sanjeevanie ${ }^{2}$
}

\begin{abstract}
A study was conducted to determine the growth and yield performances of brinjal using four different mulch materials viz. white poly mulch, silver poly mulch, paddy straw mulch and control (no mulch) in the Low country intermediate zone, Makandura, Sri Lanka. Twenty-four raised beds were prepared and treatments were arranged according to the Complete Randomized Design. Four weeks old brinjal seedlings were transplanted in the beds and fertilizer application and aftercare operations were carried out according to the recommendations of the Department of Agriculture, Sri Lanka. Data were collected on soil moisture, soil temperature, number of plants attacked by shoot and pod borer, plant height at 15, 30, 45, 60 days after transplanting and yield. Data were analyzed by Minitab 15 software. The highest plant height was recorded in paddy straw mulch. The moisture content was significantly higher in poly mulches. The lowest pest occurrence was recorded in silver mulch whilst the highest total fruit yield was obtained from white mulch $(505.6 \mathrm{~kg})$. It can be concluded that, treatments were better than the control and white mulch was superior compared to other treatments. Therefore, the white poly mulch could be
\end{abstract}

\footnotetext{
Department of Horticulture and Landscape Gardening, Faculty of Agriculture and Plantation Management, Wayamba University of Sri Lanka, Gonawila, Sri Lanka.

${ }^{2}$ Unipower (Pvt) Ltd Company, No: 756B, Liberty

Tower, Parliament Road, Battaramulla.

*dinushand@wyb.ac.lk
}

successfully used in Solanum melongena $L$. cultivation in low country intermediate zone, Sri Lanka.

Keywords: Mulching, Plasti-culture, Solanum melongena

\section{INTRODUCTION}

Solanum species (eggplants) belong to the family of Solanaceae and genus Solanum, with over 1,000 species worldwide (Agoreyo et al., 2012). Eggplant or Brinjal (Solanum melongina) is a well-known vegetable in local market as well as world market. It is originated in India (Simmon, 1979). The world annual Brinjal production is approximately 43, 173,989 MT and the area under Brinjal cultivation is $1,728,271$ ha. According to the National Horticultural Board (2010), the major producers of Brinjal are China (56.75\%), India (27.5\%), Egypt (2.85\%), Iran (2.00\%) and Turkey (1.96\%). Badulla, Hambantota and Anuradhapura are the major Brinjal cultivation areas in Sri Lanka. The Total extent of brinjal under cultivation in Sri Lanka is about 11,312 ha with total production of about $106,173 \mathrm{t}$ and an average yield of about $10.3 \mathrm{t} / \mathrm{ha}$ (AgStat, 2012).

Brinjal is used as a vegetable in all over the world and can be used as a meat 
substitute in vegetarian cuisine (Anon, 2013). Their leaves, fruits or both eaten as vegetables or used in traditional medicine (Bonsu et al., 2008; Manoko and Van der Weerden, 2004) and it consists of $92.7 \%$ moisture, $1.4 \mathrm{~g}$ protein, $0.3 \mathrm{~g}$ fat, $0.3 \mathrm{~g}$ mineral salt, $1.3 \mathrm{~g}$ fiber, and $4 \mathrm{~g}$ of carbohydrate in $100 \mathrm{~g}$ of edible portion of brinjal (Bose et al., 1986).

Mulching is a cropping practice that entails placing organic or synthetic materials on the soil close to plants to provide a more favourable environment for growth and development (Dickerson, 2002). Mulches are of two basic types organic and inorganic. Organic mulch includes hay, straw, grass and compost which provide nutrients to the soil during the decomposition process (Dickerson, 2002). In the U.S. and worldwide, polyethylene plastic mulch is extensively used for crop production because it controls weeds, conserves soil moisture, increases soil temperature, increases crop yield and quality and is readily available and at a relatively low cost (Corbin et al., 2009; Miles et al., 2012; Stapleton, 1991).

Vegetable production on raised beds with plastic mulch has become the method of choice in many parts of the country, particularly for high value crops. Plastic mulches have been used on commercial vegetable cultivation since 1960s (Lamont, 1999). Crops such as tomato, peppers, cucumber, squash, eggplant, watermelon and okra have shown significant earliness increases in yield and fruit quality when grown with plastic mulch (Bachmann,
2005; Bergholtz, 2004; Lamont, 1999). The plastic mulch aids in retention of nutrients within the root zone, permitting more efficient nutrient use by the vegetable crop (Cannington et al., 1975). Soil under the plastic mulch remain loose, friable and well aerated. Roots have access to adequate oxygen and microbial activity is enhanced (Hankin et al., 1982).

Mulch film is nearly impervious to carbon dioxide released by roots or decomposition of organic matter in the soil, and it accumulates beneath the plastic mulch (Sheldrake, 1963; Baron and Gorske, 1981). Because the film does not allow the gas to penetrate, it has to escape through the holes punched for the plants. This creates a 'chimney effect' reducing in higher levels of $\mathrm{CO}$, for the actively growing leaves near the transplant hole (Hopen, 1965). Further, Singh and Kamal (2012) reported that mulching resulted in 21.7 to $29.8 \%$ increase in fruit yield when compared to bare soil. Even though many researchers investigated mulch application on different vegetable species in different part of the world, cultivation of vegetables using different mulch types is not popularized among the Sri Lankan farmers. Therefore, this study was conducted to determine the growth and yield of Brinjal cultivated using different mulch materials in the Low Country Intermediate Zone, Makandura, Sri Lanka.

\section{MATERIALS AND METHODS Experimental Site}

This study was carried out at the Faculty of Agriculture and Plantation Management, 
Wayamba University of Sri Lanka, Makandura situated in the Low Country Intermediate Zone $\left(\mathrm{IL}_{1 \mathrm{a}}\right)$, at elevation of 300 $\mathrm{m}$ above mean sea level. The soil is moderately well drained and characterized by soft lateritic sub soil. The rainfall at Makandura during the experimental period was $4.07 \mathrm{~mm}$ while the mean relative humidity and temperature were $81.2 \%$ and $26.7^{\circ} \mathrm{C}$ respectively. The experiment was conducted during the period from March to August in 2014.

\section{Nursery Management}

The Brinjal variety "Lena iri", which is recommended by the Department of Agriculture were used for the experiment. Raised bed ( $3 \mathrm{~m} \times 1 \mathrm{~m}$ ) was prepared and it was sterilized by sandwich method (burning method). Thirty grams of seeds were sown in a nursery bed with $10 \times 5 \mathrm{~cm}$ spacing. Initially, watering was done daily, twice-aday and after the seedling emergence, watering was done thrice-per-day. Fungicide ethanethiol (captan) was applied to protect seedlings from fungal diseases. Watering and weed management were done during the nursery period (Figure 1).

\section{Land and Bed Preparation}

Land was ploughed to get a fine tilt and then pulverizing was done. All plant residues and weeds were removed. Twenty four (6 $\mathrm{m} \times 0.5 \mathrm{~m}$ ) raised beds were prepared and 48 $\mathrm{kg}$ of compost was incorporated into all the raised beds to increase the fertility of the soil. The Complete Randomized Design (CRD) consisting of six replicates and four treatments was followed as the experimental design (Table 1).

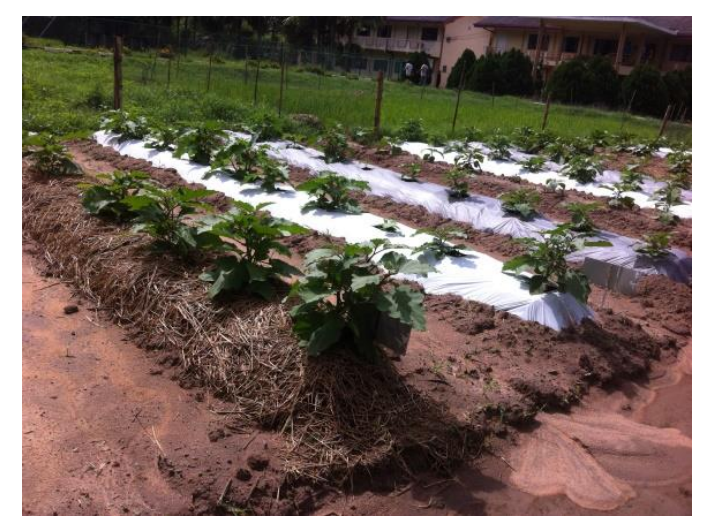

Figure 1. Different mulches used in the experiment

Table 1. Type and thickness of mulches used

\begin{tabular}{|c|c|c|}
\hline Treatment & Mulch Type & Thickness \\
\hline T1 & $\begin{array}{l}\text { Black white poly } \\
\text { mulch }\end{array}$ & $25 \mathrm{~mm}$ \\
\hline $\mathrm{T} 2$ & $\begin{array}{l}\text { Black silver poly } \\
\text { mulch }\end{array}$ & $25 \mathrm{~mm}$ \\
\hline T3 & Straw mulch & $50 \mathrm{~mm}$ \\
\hline T4 & No mulch & - \\
\hline
\end{tabular}

\section{Crop Establishment and Maintenance}

Inorganic fertilizers were applied as basal dressing to each planting hole and mixed (Table 2). Healthy, vigorous four weeks old 240 seedlings were transplanted with the spacing of $1 \mathrm{~m} \times 60 \mathrm{~cm}$. Gap filling was done up to two weeks after transplanting. Watering was done daily and manual weeding was practiced when necessary.

\section{Data Recording}

To determine the impact of mulch on the environmental factors, crop growth and the 
yield, soil temperature was taken at 5 and 10 $\mathrm{cm}$ depths using a soil thermo meter at $11.00 \mathrm{am}$ and $1.00 \mathrm{pm}$ twice a week throughout the experiment. Moisture content of the soil was taken at $15 \mathrm{~cm}$ depth from each plot twice a week. Shoot and pod borer attack was measured by observing the number of infested plants per plot. Fruits were harvested 2.5 months after transplanting and continued for a period of a month. Plant height $(\mathrm{cm})$ was measured 15, 30, 45 and 60 days after transplanting. Further, weight of fruits/plant was measured.

Table 2. Rate of fertilizer application

\begin{tabular}{|c|c|c|c|c|}
\hline \multirow{2}{*}{ Stage } & \multirow{2}{*}{$\begin{array}{l}\text { Ratio } \\
\mathrm{N}: \mathrm{P}: \mathrm{K}\end{array}$} & \multicolumn{3}{|c|}{ Applied Amount $(\mathrm{Kg} / \mathrm{ha})$} \\
\hline & & Urea & TSP & MOP \\
\hline $\begin{array}{l}\text { B.D. } \\
\text { (2 D.B.P.) }\end{array}$ & $50: 50: 50$ & 75 & 325 & 85 \\
\hline $\begin{array}{l}\text { T.D. } 1 \\
\text { (1 M.A.P.) }\end{array}$ & 50: $0: 0$ & 75 & - & - \\
\hline $\begin{array}{l}\text { T.D. } 2 \\
\text { (2 M.A.P.) }\end{array}$ & $50: 0: 50$ & 75 & - & 85 \\
\hline $\begin{array}{l}\text { T.D. } 3 \\
\text { (3 M.A.P.) }\end{array}$ & $50: 0: 50$ & 75 & - & 85 \\
\hline
\end{tabular}

BD: Basal Dressing, TD: Top Dressing; DBP: Days Before Planting; $M$ AP: Months After Planting.

\section{Data Analysis}

Data were analyzed using Minitab 15. Analysis of variance (ANOVA) was performed and means were compared by a t-test using the Fisher's Least Significant Difference (LSD) at 5\% significance level.

\section{RESULTS AND DISCUSSION}

Straw mulch recorded the highest plant height from 15 DAP to 60 DAP while the control showed the lowest height with the maturity of the plant. Among the two poly mulches, white mulch showed better height than silver mulch. There was a significant difference between white and silver mulches compared to the straw mulch and control at 15 DAP, 30 DA P and 60 DAP. At 45 DAP all the treatments were significantly different to each other (Table $3)$.
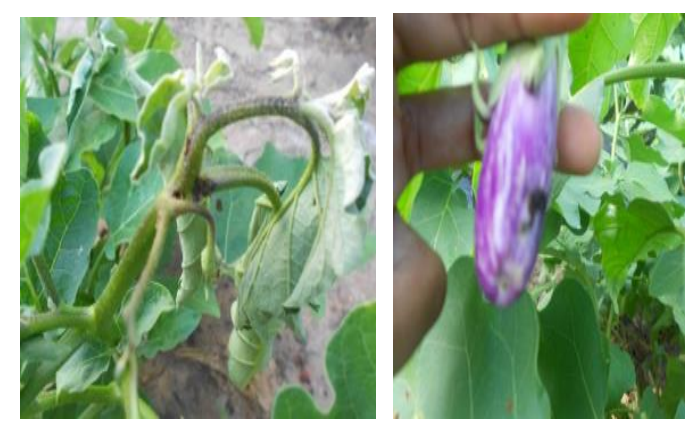

Figure 2. Shoot and pod borer damage of Brinjal

These observations indicated due to the availability of excess organic matter in straw mulch as compared to the treatments and decomposition of straw mulch by the microbes, had added more organic matter to the soil enhancing aeration and porosity. This would have helped to increase growth and development of root system and absorb more water and nutrients in straw mulched treatment (Table 3).

The moisture content under white, silver and straw mulches were significantly different from control, but were not significantly different each other. Straw mulch possessed the highest moisture content (11.427) than other treatments. 
Control had recorded the lowest moisture content (7.418) because there was no way to stop moisture evaporation from the soil. However, straw mulch retained high moisture around the plant (Weinberg, 1985) compared to others due to higher absorbance capacity of water in it (Table 4).

Table 3. Mean values for height $(\mathrm{cm})$ in different mulch types

\begin{tabular}{lllll}
\hline Treatment & 15 & 30 & 45 & 60 \\
& DAP & DAP & DAP & DAP \\
\hline White & $16.85^{\mathrm{b}}$ & $35.53^{\mathrm{b}}$ & $51.10^{\mathrm{b}}$ & $68.65^{\mathrm{b}}$ \\
Silver & $16.48^{\mathrm{b}}$ & $34.20^{\mathrm{b}}$ & $48.85^{\mathrm{c}}$ & $68.07^{\mathrm{b}}$ \\
Straw & $17.43^{\mathrm{a}}$ & $39.15^{\mathrm{a}}$ & $56.98^{\mathrm{a}}$ & $76.80^{\mathrm{a}}$ \\
Control & $12.40^{\mathrm{c}}$ & $27.88^{\mathrm{c}}$ & $40.35^{\mathrm{d}}$ & $60.90^{\mathrm{c}}$ \\
SD & 3.604 & 8.193 & 10.67 & 11.48 \\
\hline
\end{tabular}

Within each column values with same superscript letters are not significantly different at 5\% level of significance. DAP: Days after planting, SD: Standard deviation

Table 4. Mean moisture percentage in different mulch type

\begin{tabular}{lc}
\hline \multicolumn{1}{c}{ Treatment } & Moisture percentage \\
\hline White & $11.107^{\mathrm{a}}$ \\
Silver & $11.030^{\mathrm{a}}$ \\
Straw & $11.427^{\mathrm{a}}$ \\
Control & $7.418^{\mathrm{b}}$ \\
SD & 1.797 \\
\hline
\end{tabular}

Within each column values with same superscript letters are not significantly different at $5 \%$ level of significance.

The only pest found in the field was shoot and pod borer (Luecinoides orbonalis) (Figure 2). There was no any other pest and diseases found. The highest pest incidence (6) was observed in straw mulch (Figure 3) due to the moisture high environment around the plants (Moody et al., 1965) (Table 4). Silver poly mulch recorded the lowest pest incidence (3). This may have been due to the silver mulch providing a cooler soil environment and repellant ability of pest due to its colour (Lament, 1993). Reflected light seems to prevent pest from seeing the plants. In all the treatments pod attack by shoot and pod borer was very low compared to shoot attacks.

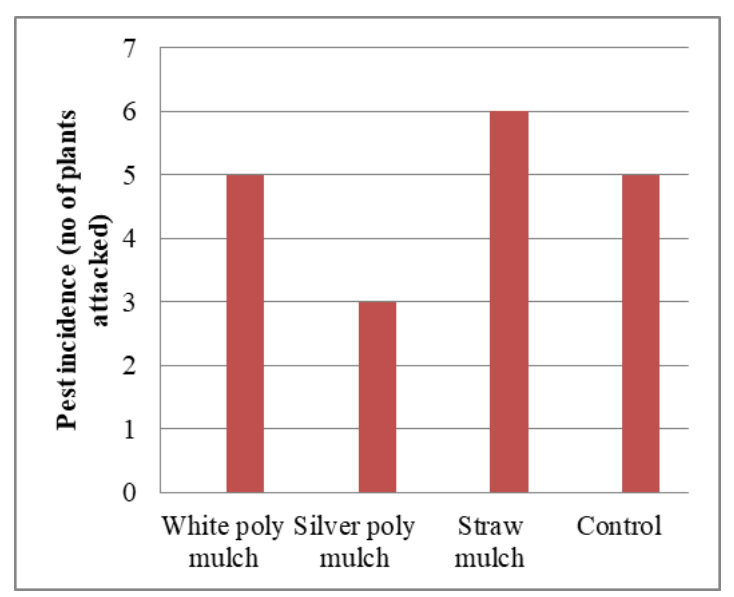

Figure 3. Median values for pest and disease incidence

The surface colour of plastic mulch can change the quantity of light and spectral balance reaching to plants, with result in effects on growth and fruit production (Fortnum et al., 1995). On the other hand, plastic mulches often enhanced soil temperatures under the mulch covering and provided better yield. There was a significant difference between four different treatments.

The highest pod yield was obtained from white mulch $(505.6 \mathrm{~kg})$ where yield increase was $200 \%$ and the lowest pod yield was recorded in the control $(248.9 \mathrm{~kg})$. 
Recorded pod yield in white mulch was doubled compared to un-mulched soil, while silver mulch and straw mulch were resulted an average yield increase (Table 5). The yield increases of the crops due to white mulch have been attributed to an increasing of reflected solar radiation (Rosenberg, 1974).

Table 5. Mean pod yield of different mulch type

\begin{tabular}{lcc}
\hline Treatment & $\begin{array}{c}\text { Total Yield } \\
(\mathrm{Kg})\end{array}$ & $\begin{array}{c}\text { Yield Increase } \\
\%\end{array}$ \\
\hline White & $505.6^{\mathrm{d}}$ & 200 \\
Silver & $475.5^{\mathrm{c}}$ & 192 \\
Straw & $449.0^{\mathrm{b}}$ & 180 \\
Control & $248.9^{\mathrm{a}}$ & 100 \\
SD & 265.2 & \\
\hline
\end{tabular}

Within each column values with same superscript letters are not significantly different at $5 \%$ level of significance.

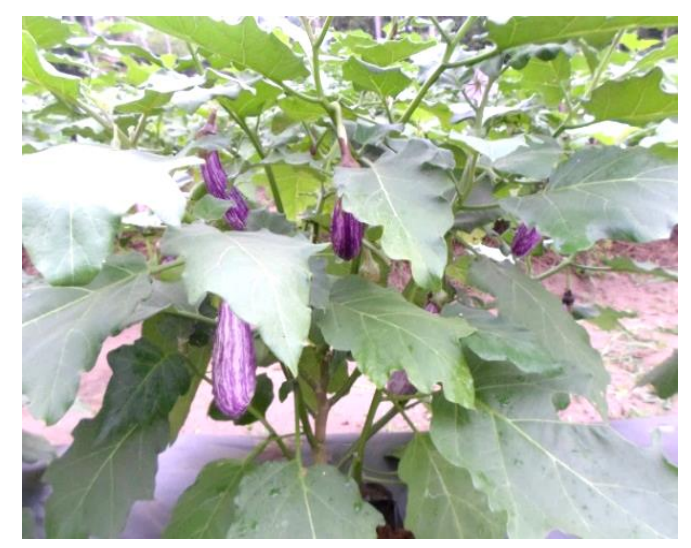

Figure 4. Plants grown with silver mulch

White and silver mulch absorbs little solar radiation but transmits more with relative transmission depending on the thickness and degree of opacity of the polyethylene. The under surface of these plastic mulch is covered with condensed water droplets. This water is transparent to incoming shortwave radiation but is opaque to outgoing long wave infrared radiation (Ham et al., 1993), therefore, much of the heat lost to the atmosphere from a bare soil by infrared radiation is retained by clear plastic mulch. Thus, daytime soil temperatures under white and silver mulches were generally $30{ }^{\circ} \mathrm{C}$ at both $5 \mathrm{~cm}$ and $10 \mathrm{~cm}$ depth and $1{ }^{\circ} \mathrm{C}$ higher compared with bare soil. But in afternoon, highest temperature at $5 \mathrm{~cm}$ depth in silver mulch and at $10 \mathrm{~cm}$ depth in control were observed. There was no any significant difference among four treatments (Table 6).

Table 6. Mean values for soil temperature $\left({ }^{0} \mathrm{C}\right)$ in different mulch types

\begin{tabular}{|c|c|c|c|c|}
\hline Treatment & $\begin{array}{l}11 \mathrm{am} \\
(5 \mathrm{~cm})\end{array}$ & $\begin{array}{l}11 \mathrm{am} \\
(10 \mathrm{~cm})\end{array}$ & $\begin{array}{l}1 \mathrm{pm} \\
(5 \mathrm{~cm})\end{array}$ & $\begin{array}{l}1 \mathrm{pm} \\
(10 \mathrm{~cm})\end{array}$ \\
\hline White & $\begin{array}{l}30.200 \\
\mathrm{a}\end{array}$ & $30.217^{\mathrm{a}}$ & $30.367^{\mathrm{a}}$ & $32.367^{a}$ \\
\hline Silver & $\begin{array}{l}30.270 \\
\mathrm{a}\end{array}$ & $30.450^{\mathrm{a}}$ & $30.633^{a}$ & $\begin{array}{l}32.900 \\
\mathrm{a}\end{array}$ \\
\hline Straw & $\begin{array}{l}29.567 \\
\mathrm{a}\end{array}$ & $29.900^{a}$ & $29.983^{a}$ & $32.000^{\mathrm{a}}$ \\
\hline Control & $\begin{array}{l}29.417 \\
\mathrm{a}\end{array}$ & $30.383^{a}$ & $30.283^{a}$ & $33.667^{\mathrm{a}}$ \\
\hline SD & 0.301 & 0.407 & 0.361 & 0.742 \\
\hline
\end{tabular}

\section{CONCLUSION}

Results revealed that adding mulch could improve the performance of Brinjal and the yield was significantly high in white mulch followed by silver mulch and in straw mulch compared to the control. Though the white mulch recorded high shoot and pod borer attack compared to silver mulch, due to its significantly high yield, white mulch can be recommended as the best mulch type out of the treatments studied to be used with Brinjal cultivation in the low country 
intermediate zone of Sri Lanka.

\section{ACKNOWLEDGEMENT}

Authors gratefully acknowledge the support given by the Unipower Private Limited by providing poly mulches. Sincere thanks are extended to the nonacademic staff of Department of Horticulture and Landscape Gardening, Wayamba University of Sri Lanka for providing field assistance.

\section{REFERENCES}

Agoreyo, B.O., Obansa, E.S. and Obanor, E.O. (2012). Comparative nutritional and phytochemical analyses of two varieties of Solanum melongena. Science World Journal. 7(1): 16-17.

Ag Stat, (2012). Socio economic and Planning Centre, Department of Agriculture, Gannoruwa, Peradeniya, Sri Lanka, 28.

Anon, (2013).Vegetarian meat substitutes, Available from: http://www.vegetarians.co.nz/articles/ vegetarian.meatsubstitutes/. (Accessed 20 April 2014).

Bachmann, J. (2005). Season Extension Techniques for Market Gardens. ATTRA (online). Available from: http//:www.attra.ncs,org. (Accessed 20 April 2014).

Baron, J. J. and Gorske, S. F. (1981). Soil carbon dioxide levels as affected by plastic mu lches. In Proceedings of $16^{\text {th }}$ National Agricultural Plastics Congress, 149-155.

Bergholt, Z. P. (2004). Ken - BAR
Products for the Growers: Agricultural plastics. KENBA R, Inc., Read ing, MA. (Online). Available from: http//:www.kenbar.com. (Accessed 20 April 2014).

Bonsu, K.O., Fontem, D. A., Nkansah, G. O., Iruo me R.N., Owusu E.O. and Schippers, R.R. (2008). Diversity with in the Gboma eggplant (Solanum marcocarpon), an indigenous vegetable from West Africa. Ghana Journal of Horticulture. 1: 50-58.

Bose, T.K., Som, M.G. and Kabir, J. (1986). Vegetable crops. Naya Prokash, India, 281-319.

Cannington, F., Duggings, R.B. and Roanmu, L. (1975). Cooperative Extension Service, New Mexico State University, Las Cruces, N.M, 245.

Corbin, A., Miles, C., Hayes, D., Dorgan, J. and Rozen, J. (2009). Sustainability of biodegradable plastic mulches. In Certified organic production. American society of Horticulture conference, S. Louis, Missouri.

Fortnum, B.A., Decoteau, M.J. Kasperbauer and Bridges, W. (1995). Effect of colored mulch on rootknot of tomato. Phytopathology, 85: 312-318.

Hankin, L., Hill, D.E. and Stephens, G.R. (1982). Effects of mulches on bacterial population and enzyme activity in soil and vegetable yields. Plant \& Soil Science, 64: 193-201.

Ham, J.M. and G.J. Kluitenberg. (1994). Modeling the effect of mulch optical properties and mulch-soil contact resistance on soil heating under plastic mulch culture. Agriculture for Meteorology, 71: 403-424. 
H.D.S.N. Wijesooriya, R.D.N. Debarawatta, K. Yakandawala, R. Dabarera and W.A.P. Sanjeevanie

Hopen, H.J. (1965). Effects of black and transparent polyethylene mulches on soil temperature, sweet corn growth and maturity in a cool growing season. Journal of American Society of Horticultural Science, 86: 415-423.

Lamont, W.J. (1999). The use of differnt different colored mulches for yield and earliness. In Proceedings of the New England Vegetable and Berry Growers Conference and Trade Show, Sturbridge, Mass, 299 - 302.

Lamont, W.J. (1993). Plastic Mulches for the Production of Vegetable Crops, HortTechnology, 3(1): 35 - 39.

Manoko, M.L.K. and Van der Weerden, G. M. (2004). Solanum americanum. In: G. J. H. Grubben and O. A. Denton (eds.), Plant Resources of Tropical Africa.

Miles, C., Wallace. R., Wszelaki, J., Cowan, J., Walter, T. and Inglis, D. (2012). Durability of potentially biodegradable alternatives to plastic mulch three tomato production regions. HortScience, 47(9): 1270 1277.

Moody, J. E., Jones, J. N. and Lillard, J. H. (1965). Influence of straw mulch on soil moisture, soil temperature and the growth of corn. Science Society of American Journal, 27(6): 700 - 703.

National Horticultural Board, (2010). Available from: http://nhb.gov.in/. (Accessed 20 April 2014).

Rosenberg, N.J. (1974). Microclimate: the biological environment. New York, Wiley Inter-science.

Sheldrake, R. (1963). Carbon dioxide levels in the microclimate influences insect control and yield in vegetables. Journal of American Society of Horticultural science, 104, 759-962.

Simmonds, N.W. (1979). Evolution of crop plants. Longman Science and Technology.

Stapleton, J.J. (1991). Use of soil solarization for the control of soil pests. In Proceedings of $23 \mathrm{rd}$ National Agricultural Plastics Congress, 266271.

Singh, A.K. and Kamal, S. (2012). Effect of black plastic mulch on soil temperature and tomato yield in hills of Garwal Himalayas. Journal of Horticulture and Forestry, 4(4): 78-80.

Weinberg, J.B. (1985). Growing Food in the High Desert Country, Sunstone Press, 39. 